\title{
Correction to: Economic growth and political extremism
}

\author{
Markus Brückner ${ }^{1} \cdot$ Hans Peter Grüner ${ }^{2,3}$
}

Published online: 23 September 2020

(c) Springer Science+Business Media, LLC, part of Springer Nature 2020

\section{Correction to: Public Choice (2020) 185:131-159 https://doi.org/10.1007/s11127-019-00745-w}

This article was published in Public Choice 185:1-2 and is part of the "Special Issue of Public Choice in Honor of the 90th Birthday of Peter Bernholz/Edited by Arye L. Hillman and Heinrich W. Ursprung".

Publisher's Note Springer Nature remains neutral with regard to jurisdictional claims in published maps and institutional affiliations.

The original article can be found online at https://doi.org/10.1007/s11127-019-00745-w.

\section{Markus Brückner}

markus.brueckner@anu.edu.au

Hans Peter Grüner

hgruener@staffmail.uni-mannheim.de

1 Research School of Economics, Australian National University, Acton, Canberra 0200, Australia

2 Department of Economics, University of Mannheim, L 7, 3-5, 68131 Mannheim, Germany

3 CEPR, London, UK 